\title{
Interleukin Therapy
}

National Cancer Institute

\section{Source}

National Cancer Institute. Interleukin Therapy. NCI Thesaurus. Code C15543.

The use of interleukin in the treatment of any disease or disorder. 